\title{
A Social Aspect Of Increasing Trend Of Sheesha Smoking Among Youth
}

\author{
Syeda Farhana Sarfaraz \\ Sakina Riaz \\ \& \\ Sumera Ishrat \\ Department of Social Work \\ University of Karachi
}

\begin{abstract}
In Pakistan traditionally used hookah is now known as sheesha with a little difference in its texture and usage. Now sheesha contains different flavors and very popular among youth without considering its consequences. In this study researchers wants to highlight the level of awareness, socio-economic and educational background, practices, causes and general consequences among sheesha users in Karachi. A sample of 296 respondents was selected for this study which comprised of 217 (73\%) male and $79(27 \%)$ female. All of them belong to the age group of 18-30 years. Most of them were students of various public and private institutes. $142(48 \%)$ respondents were regular sheesha smokers, $30 \%$ daily while $22 \%$ were occasional sheesha smoker. $34 \%$ started sheesha smoking at the age of 11-15 years. The majority of the respondent claims that the cause of sheesha smoking was the peer pressure in social and friend gatherings. A vast majority didn't consider sheesha smoking harmful for health and they are unaware about the health hazards of this habit. In this circumstances, parents should keep an eye on the out-door activities of their children, all the public and private machinery should participate in awareness creating campaign against health hazards of sheesha smoking in all educational institutes countrywide along with this laws should be also fully implemented to rescue our youth from this life threatening habit.
\end{abstract}

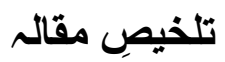

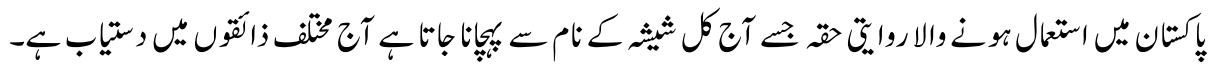

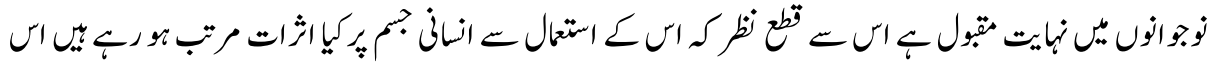

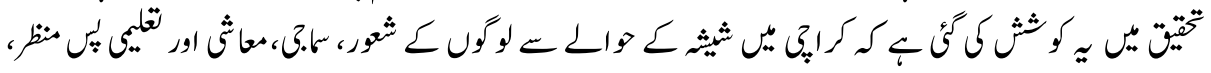

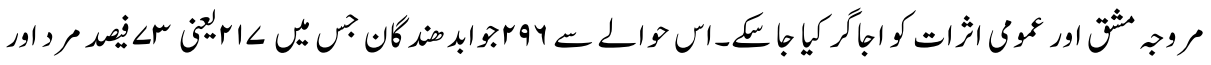

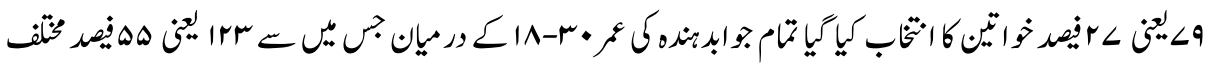

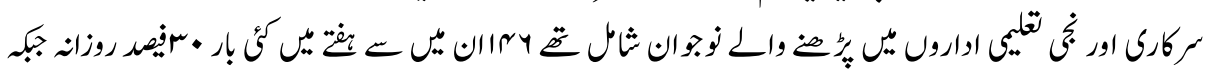

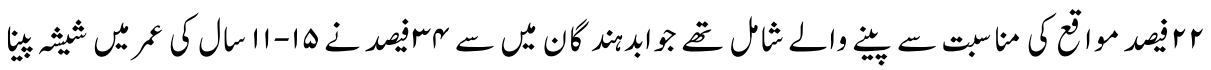

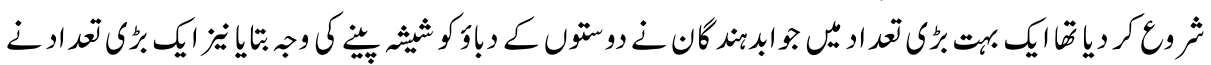

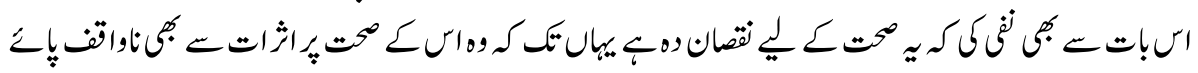




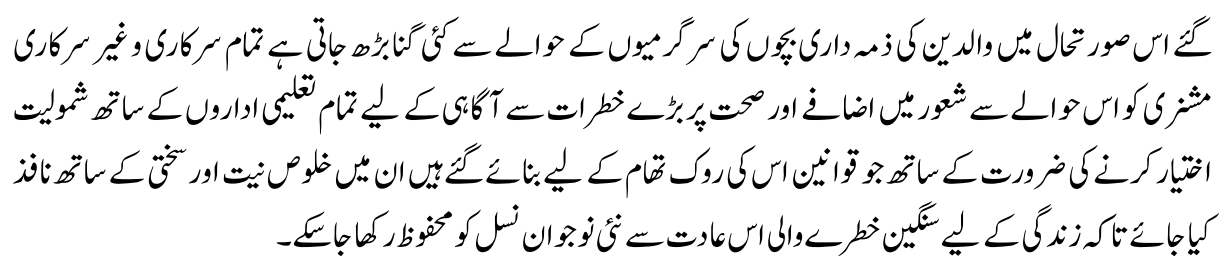

Keywords: Sheesha smoking, youth.

\section{Introduction and Background}

In the turn of the $21^{\text {st }}$ century many transforms has occurred in the life of a common person, for many it has improved the quality of life. Regardless of all the positive advancements, the $21^{\text {st }}$ century also witnessed an unprecedented rise in elements which destroy human life. Out of these, tobacco remains the number one factor adversely affecting the health of humans. Though the developed world has controlled its usage, by strong legislation yet no such laws are properly enforced in developing countries. Tobacco consumption has transformed in to fashionable forms of tobacco usage such as hookah or sheesha smoking. In adolescents and youth, the increasing trend of smoking sheesha is mostly attributed to lack of knowledge and the misconceptions regarding its use. It is now commonly available in café's, restaurants and even at homes. Unfortunately, the most common users are at universities or colleges.

Use of Tobacco in any form is deadly. Smoking kills more than half of all its regular users. According to WHO 2008, the annual death toll attributable to tobacco is expected to rise from current estimates of 5-4 million per year to 10 million per year by 2025 and over $70 \%$ of these deaths would be in developing countries.

Tobacco is the single most preventable cause of disease and death in the world today. In most countries of the world, important measures have been taken to control this epidemic such measures include implementation of clean air laws increased taxations of tobacco products, educating the public on tobacco hazards and pictorial warning on cigarettes packs. Unfortunately Pakistan is lagging behind the rest of the world in its effort to control this epidemic.

Tobacco use is also a major risk factor for heart attacks, stroke, pneumonia, chronic lung disease as well as many others serious diseases like lungs and oral cancer. Tobacco smoke is a complex of gas and particles that contains over 400 chemicals, 60 of which are known to cause cancer. Second hand smoking is equally hazardous and causes number of diseases. (Khan: 2012)

Tobacco is the name of the solavancia family (night shade family) and the dried leaves used in cigars, cigarettes, snuff pipe, chewing tobacco and new flavoured sheesha. It can 
be used as a pesticide and extracts from ingredients of same medicine but it is most commonly consumed as s drug. Because of the powerful addictive properties of tobacco, tolerance and dependence is developed, the usage of tobacco is an activity that is practiced by 1.1 billion people and up to $1 / 3$ of the adult population. Tobacco use remains highly prevalent in Pakistan, with rates of as high as $3 \%$ among middle aged males. These are much diversity in the form of tobacco use in Pakistan including cigarettes, beads, chewing tobacco, hookah and chillum. According to large scale survey, one in every fine Pakistani males has consumed more than 100 cigarettes/beads or chillum hookah in his life time. (Ahmad K. et al: 2005)

In the last century a decline was seen in hookah usage and was mostly confirmed to older man in rural areas recently a global resurgence has been seen in hookah smoking, including Pakistan where it is commonly known as "Sheesha" among the younger generation. The reasons accredited to this trend are certain misconceptions that sheesha smoking is not hazardous to health, since the tobacco is filtered through water before inhalation; nicotine content is less than that if the cigarettes and addition of fruits flavors make it healthier. Another factor adding to its popularity is its social acceptability as compared to cigarettes and its portrayal is a symbol of modernization of our cultural heritage.

Hookah smoking known as sheesha, narghile, Hubble bubble and Ghoza in different countries and culture, is a form of tobacco intake in which the smoke passes through water before inhalation traditionally sheesha is a single stemmed (often glass based) water pipe for smoking the most ancient traces were found in Ethiopia and Africa. It gained immense popularity in many Arab countries and Middle East. Sheesha was introduced in subcontinent during Akbar regime 1542-1605 AD. A Persian physician Hakim Abdul Fateh Gillani invented hookah which allowed smoke passed through water in order to be purified. He encouraged Akbar to take up the smoking device. The use of sheesha is a 400 years old method of smoking tobacco. It has been reported that more than 100 million people worldwide smoke sheesha. It is typically smoked in social settings, where water pipes are passed from person to person and typically smoking sessions last between 45 and 50 minutes but many continue for several hours (Wikipedia).

The word comes from a Persian word for glows. The term sheesha is primarily used for water pipe in Egypt. Misinformed westerners tend to refer to the tobacco smoked from a water pipe as sheesha. This is used as slang use in Middle East where it is acceptable to request a flavoured sheesha which means a sheesha with a flavoured tobacco. The incorrect influence that sheesha refers to the flavoured tobacco spread into the vernacular and it is primarily used by those that have only experienced this particular aspect of Middle East culture in its cheaper commercialized form in to the west. In Middle East this is called as sheesha whereas in Iran it is noticed Ghalyum. Sheesha again drawn acceptance in the sub-continent and the hotels and restaurants gives sheesha are more 
famous those who smoke Hookah. The rich and advanced public of turkey took selfconfidence is smoking sheesha and expands it into what we now see in our world. By sheesha we provide in the hotels and coffee homes in turkey about the two-three centuries ago (Wikipedia).

Nowadays, different local and international brands, their types are available in the markets with online information and details. Sheesha is available in various flavours as well like Apple, Apricot, Bahraini, Banana, Cherry, Chocolates, Blackberry, Grapes, Cappuccino, and Cardamom Cafflette etc.

\section{General Structure of Sheesha}

A sheesha consists of a number of components excluding grommets. a bowl, wind screen, hose, purge valve, water jar, plate, grommets and diffuser.

The jar at the bottom of the sheesha is filled with water sufficient to submerge a few centimeters of the body tube, which is sealed tightly to it. Deeper water will only increase the inhalation force needed to use it. Tobacco is placed inside the bowl at the top of sheesha and then a foil or charcoal screen with a burning charcoal is placed on top. Where one inhales through the hose air is pulled through the charcoal and into the bowl holding the tobacco. The hot air heated by the charcoal vaporizes the tobacco, thus producing smoke, which is passed down through the body tube that extends into the water jar. It bubbles up through the water, losing heat and fills the top part of the jar, to which the hose is attached. When a smoker inhales from the hose, smoke passes into the lungs and the change in pressure in the jar pulls more air through the charcoal, continuing the process.

Over the last decades, compelling evidence regarding the hazards of sheesha smoking accumulated in the literature. Smoking is recognized as a health problem worldwide. It has been proven that long term habitual abuse of sheesha is associated with lung gastro intestinal and bladder problems and haematological diseases, which has been assumed to spread from pipe sharing and its manual preparation. The tragedy is that most of the users did know that sheesha smoke contained tobacco; even through the nicotine content of sheesha tobacco has been reported as $2 \%$ to $4 \%$ as compared to $3 \%$ for cigarettes. Its smoke also contains hundreds of potentially dangerous substances including carbon monoxide charcoal, nicotine, arsenic cobalt, chromium and lead. (Maziak: 2004: 327)

A typical hour long sheesha session involves inhaling 100 to 200 times volume of smoke inhaled as compared to smoking a cigarette. In addition, sheesha smokers might absorbs higher concentration in the smoke itself, or because they may smoke for several hours at a time and may inhale the moisturized, less irritating smoke more deeply. A recent study done in Pakistan showed that curiosity followed by pleasure seeking and boredom are the 
most important factors in starting sheesha smoking. The majority of these participants thought of cigarettes smoking as being more harmful as compared to sheesha smoking. (Jawaid et al. 2008).

Smokers are at an increased risk of developing several serious and potentially fatal diseases such as heart diseases cancer and respiratory illness (US department of health and human services, 2004). Several studies suggest that smokers may experience more sleep disturbance than nonsmokers (Phillips metal, 1995). The world health organization pronounce North Africa, east Mediterranean region and south East Asia to have the highest rate of water pipe smoking (WHO 2005).

Several factors may contribute to the rising popularity of sheesha use. Sheesha is cheap and widely available facility, its common among youth and it is often considered a social activity. Many smokers mistakenly believe that sheesha is less harmful than other methods of tobacco use. According to WHO report, $32.4 \%$ males and $5.7 \%$ female are currently tobacco smokers in Pakistan, in which $43 \%$ male and $11 \%$ female university students were found to be a regular sheesha users (WHO, 2011). Significant number of people also use smokers tobacco in the form of pan, gutka, naswar etc. Rising trend of smoking in the adolescent female in Pakistan is also a cause of serious concern. (Ganatra et al. 2007); (Nawaz et al. 2009)

On the basis of review of the available literature we found following general effects of sheesha smoking:

1. Sheesha smokers inhale large volume of tobacco smoke in one session than cigarettes.

2. Water in the sheesha bowl doesn't filter out the nicotine and other harmful toxic ingredients.

3. Irritation from exposure to tobacco juices increases the risk of developing oral cancer.

4. Hookah pipe used in sheesha bases in cafés and restaurants may not be cleaned properly increases the risk of infectious diseases.

5. Sheesha smoking among pregnant women is a risky practice for their babies as well, since the child may face low weight or difficulty in breathing.

6. Sharing a sheesha increases the risk of transmitting, hepatitis and other communicable diseases.

7. Sheesha tobacco contains numerous toxic substances known to cause heart diseases, asthma, cancer, lung diseases and many mental disorders.

8. Sheesha smoking can increases wrinkles and speed up the aging process. Although the hazards of sheesha smoking have been well characterized but they are not understood by the general population. 


\section{Global Situation}

Global situation in the Middle East and Arab areas, people smoke sheesha as a part of their culture and tradition. Most cafes in the Middle East offer sheesha in cafes. It is widespread and are amongst the chief social gathering places. Saudi Arabia is in the process of implementing general smoking bars in public places and governments offices also provide a place for sheesha smoking. In Syria sheesha is widely used and usually called argila. It is easily available at almost every corner. It is normal to see a female smoking sheesha in Syria. Narghile is a Turkish name of sheesha western turkey is noted for its traditional pottery production including sheesha bowl tobacco is smoked in hookahs in many villages as a traditional custom. Smoking tobacco molasses is now becoming popular amongst the youth in India. There are several chain clubs, bars and coffee shops in India where a wider variety of molasses is available. Hookah specially wooden ones, also becoming popular among younger people and tourists in Nepal. In Bangladesh hookah lounges spread quite quickly during the period of 2008-2011. It is very popular among young generation and middle aged man as a method of relaxation. In South Africa, it is called Hubble bubble, widely used in homes, public places sites and beaches. In U.S.A and Canada, indoor sheesha smoking is banned but hookah lounges are growing in popularity.

\section{Contemporary Situation in Pakistan}

Sheesha smoking has become very popular in Pakistan. Many restaurants and cafes are offering sheesha in Karachi, Islamabad, Lahore and other cities of the country. This flavoured pipe is gaining popularity among the younger generations.

Fashion and addiction are two completely different and most commonly used terms but when it comes to Sheesha smoking it is hard to consider these two as separate. Sheesha smoking in Pakistan is nowadays becoming fashion in youngsters. Popularity of sheesha in people can be well estimated by observing the mushrooms growth of sheesha cafes generally all round the world and especially in Pakistan. In Pakistan traditionally used hookah is now known as sheesha with a little difference in its texture and usage. Now sheesha or latest hookah contains different flavours which are highly popular and used among lots of people without taking into account its consequences. Just because smoke in sheesha is passed through water people think that it becomes safe to smoke sheesha because water absorbs the amount of nicotine present in the smoke and due to the different fruit flavours it is not harmful for human body. They are ignorant of the fact that smoke in any form is dangerous either it passes through water or contains fruit flavour, once you inhale smoke it definitely harm your body. Smoke of sheesha after mixing with water becomes more toxic and even more dangerous than normal smoking. Additional danger which was not encountered with cigarette smoking are in fashion diseases infection resulting from pipe sharing and frequent addition of alcohol and psycho active 
drugs with the tobacco. Many people use wine instead of water for better taste. Many children are not aware about sheesha cafes they usually go to smoke in which some addictives are mixed just to make it their habit. Majority of the elder people use sheesha as it is an old form of hookah. Nowadays sheesha smoking is a fashion and status symbol. Another tragedy is that even girls are using shish very frequently. Normally parents in Pakistan do not permit their daughters to smoke cigarette but allow them to smoke sheesha because they think that cigarette is more harmful as compared to sheesha. Instead they think sheesha contains flavour so it is not harmful and a healthy practice.

For girls sheesha use is very exciting, glamorous, fashionable and enjoyable activity. In fact girls are more sensitive as compared to boys, the danger cause to girls is more severe in nature then boys. During pregnancy a mother and her foetus has connected blood system so that cancer causing chemicals like tobacco can pass through placenta, the tissues and blood vessels which nourish a foetus. As a result following problems may occur during pregnancy:

- A chance of miscarriage or still birth, premature births, under weight babies.

- Babies have learning and behaviour problems in later childhood.

- Increase risk of death from a condition known as sudden infant death syndrome.

\section{Methodology}

This cross sectioned study was carried out during the second half of 2012 across different areas in Karachi where Sheesha bar are situated, including North Nazimabad, Gulshan e Iqbal, Gulistan e Johor, DHA and Clifton. A sample size of 296 respondents was selected through purposive sampling from different sheesha café's, restaurants and shopping malls. Respondents selected in the study were all students aged between 18-30 years. They all were regular smokers of sheesha. A self-administrated questionnaire was developed consisting of 47 items instrument. After pre testing it was finalized. The data was analyzed by simple frequency distribution tables.

\section{Results and Discussion}

The demographic results of the respondents shows male 217 (73\%) and females 79 (29\%). 196 (66\%) respondents were Urdu speaking, 49 (16\%) were Punjabi 30(10\%) Pashto $9(25 \%)$ Sindhi and (2\%) belong to other languages. $(58 \%)$ were single $21 \%$ were engaged $19 \%$ were married. 55\% were students $26 \%$ were professional. $73 \%$ were living in their own houses and $27 \%$ were live in rented houses. $67 \%$ were belonging to urban background and $33 \%$ had rural background. $54 \%$ of the respondent were from joint family system and $46 \%$ from nuclear family system. The average household income varied from PKR 10,000 to 60,000. 
Table 1

Frequency distribution of respondents according the awareness regarding harmful effects of sheesha smoking on health

\begin{tabular}{|l|c|c|}
\hline Response & F & $\%$ \\
\hline Yes & 195 & $65 \%$ \\
\hline No & 101 & $35 \%$ \\
\hline Total & $\mathbf{2 9 6}$ & $\mathbf{1 0 0 \%}$ \\
\hline
\end{tabular}

$65 \%$ of the respondents considered sheesha as not harmful to their health and $35 \%$ realized that somehow sheesha smoking is harmful for health.

Table 2

Frequency distribution of respondents about knowledge of health hazards caused by sheesha

\begin{tabular}{|c|c|c|}
\hline Response & f & $\%$ \\
\hline $\begin{array}{l}\text { a. } \\
\text { Harmful effects } \\
\text { Harmful than } \\
\text { cigarettes } \\
\text { less Harmful than } \\
\text { cigarettes } \\
\text { Don't know }\end{array}$ & $\begin{array}{c}70 \\
201 \\
25\end{array}$ & $\begin{array}{l}24 \% \\
68 \% \\
8 \%\end{array}$ \\
\hline $\begin{array}{l}\text { b. } \frac{\text { Addiction }}{\text { Addictive than }} \\
\text { cigarettes } \\
\text { Less addictive than } \\
\text { cigarettes } \\
\text { Don't know }\end{array}$ & $\begin{array}{r}65 \\
196 \\
35\end{array}$ & $\begin{array}{l}27 \% \\
66 \% \\
12 \% \\
\end{array}$ \\
\hline $\begin{array}{l}\text { c. } \frac{\text { Water filters the }}{\text { toxins out }} \\
\text { Yes } \\
\text { No }\end{array}$ & $\begin{array}{l}188 \\
108\end{array}$ & $\begin{array}{l}63 \% \\
37 \%\end{array}$ \\
\hline $\begin{array}{l}\text { d. } \frac{\text { Presence of Tar in }}{\text { sheesha smoking }} \\
\text { Yes } \\
\text { No }\end{array}$ & $\begin{array}{l}101 \\
195\end{array}$ & $\begin{array}{l}35 \% \\
65 \%\end{array}$ \\
\hline $\begin{array}{l}\text { e. } \frac{\text { Contains Nico tine }}{\text { sheesha smoking }} \\
\text { yes } \\
\text { No }\end{array}$ & $\begin{array}{l}106 \\
190\end{array}$ & $\begin{array}{l}36 \% \\
64 \%\end{array}$ \\
\hline
\end{tabular}


It is a multiple response table which shows the knowledge of respondents about the harmful ingredients of sheesha. A vast majority of them $(68 \%)$ considered sheesha is less harmful than cigarettes. $66 \%$ claimed that sheesha is also less addictive than cigarettes. $63 \%$ believes that, in sheesha the presence of water filters out the toxins, whereas $65 \%$ was not aware of the fact that tar as well as nicotine are among the ingredients of any sheesha

\section{Table 3}

Frequency distribution of respondents according to their age of starting of sheesha smoking

\begin{tabular}{|l|c|c|}
\hline Age & f & \% \\
\hline Before 11 years & 38 & $12 \%$ \\
\hline $11-15$ yrs. & 100 & $34 \%$ \\
\hline $16-20$ yrs. & 76 & $27 \%$ \\
\hline $21-25$ yrs. & 82 & $27 \%$ \\
\hline Total & $\mathbf{2 9 6}$ & $\mathbf{1 0 0}$ \\
\hline
\end{tabular}

$34 \%$ started sheesha smoking from age bracket of $11-15$ yrs., $27 \%$ from $16-20 \mathrm{yrs}, 27 \%$ from $21-25 y$ rs, and $12 \%$ indulge in this habit before, the age of 11 years.

Table 4

Frequency distribution of respondents according to the use sheesha

\begin{tabular}{|l|c|c|}
\hline Use of Sheesha & $\mathrm{F}$ & $\%$ \\
\hline Daily & 89 & $30 \%$ \\
\hline Regular & 142 & $48 \%$ \\
\hline Occasional & 65 & $22 \%$ \\
\hline Total & $\mathbf{2 9 6}$ & $\mathbf{1 0 0}$ \\
\hline
\end{tabular}

$48 \%$ were regular sheesha smokers, while $30 \%$ daily and $22 \%$ were occasional users of sheesha. In Karachi boys usually have the opportunity to go outside the house for many reasons but girls don't have.

Table 5

Frequency distribution of respondents according to who introduce sheesha smoking?

\begin{tabular}{|l|c|c|}
\hline Response & $\boldsymbol{f}$ & Percentage \\
\hline Due to peer pressure & 190 & $64 \%$ \\
\hline Introduce & 82 & $28 \%$ \\
\hline Others & 24 & $08 \%$ \\
\hline Total & $\mathbf{2 9 6}$ & $\mathbf{1 0 0 \%}$ \\
\hline
\end{tabular}


Highest numbers of respondents that is $64 \%$ started sheesha smoking due to peer pressure, $28 \%$ due to family members and $8 \%$ started because of other than these people.

Table 6

Frequency distribution of respondents according to the reason they continue sheesha smoking

\begin{tabular}{|l|c|c|}
\hline Reason & F & \% \\
\hline For and entertainment & 190 & $65 \%$ \\
\hline Sheesha smoking for pleasure & 80 & $27 \%$ \\
\hline Family culture & 24 & $8 \%$ \\
\hline Total & $\mathbf{2 9 6}$ & $\mathbf{1 0 0}$ \\
\hline
\end{tabular}

$68 \%$ used sheesha for fun and entertainment, whereas $29 \%$ for fashion and status purpose and $8 \%$ continued this habit because of family culture.

Table 7

Frequency distribution of respondents according to their habit other than sheesha smoking

\begin{tabular}{|l|c|c|}
\hline Response & Number & \% \\
\hline Cigarettes & 176 & $59 \%$ \\
\hline Pan, Gutka & 106 & $36 \%$ \\
\hline Alcohol & 14 & $5 \%$ \\
\hline Total & $\mathbf{2 9 6}$ & $\mathbf{1 0 0}$ \\
\hline
\end{tabular}

$59 \%$ of the respondents smokes cigarettes as well, $36 \%$ were habitual of using pan, gutka and supari while were $5 \%$ also alcohol adducted.

Table 8

Frequency distribution of respondents according to the Knowledge of their Family regarding sheesha smoking habit

\begin{tabular}{|l|c|c|}
\hline Response & F & \% \\
\hline $\begin{array}{l}\text { Know about sheesha } \\
\text { smoking }\end{array}$ & 156 & $53 \%$ \\
\hline $\begin{array}{l}\text { Doesn't know about } \\
\text { sheesha habit }\end{array}$ & 140 & $47 \%$ \\
\hline Total & $\mathbf{2 9 6}$ & $\mathbf{1 0 0}$ \\
\hline
\end{tabular}

$53 \%$ of the respondents family were aware of their habit of sheesha smoking, while remaining $47 \%$ respondents family were not ever aware about their sheesha smoking. 
Table 9

Frequency distribution of respondents according the expenses of sheesha smoking

\begin{tabular}{|l|c|c|}
\hline Response & f & \% \\
\hline Contribution with friends & 89 & $30 \%$ \\
\hline Own expenses & 92 & $31 \%$ \\
\hline Pocket money (family) & 53 & $18 \%$ \\
\hline Friends & 62 & $21 \%$ \\
\hline Total & $\mathbf{2 9 6}$ & $\mathbf{1 0 0}$ \\
\hline
\end{tabular}

$31 \%$ of the respondents bearded expenses of sheesha by their own, $30 \%$ said their friends contributed equally, $21 \%$ indicated their friends bearded whole expenses while $18 \%$ claimed that they use their pocket money for the purpose.

Table 10

Frequency distribution of respondents according to the general consequences of sheesha smoking

\begin{tabular}{|l|c|c|}
\hline Consequences & F & \% \\
\hline $\begin{array}{l}\text { Lack of interest in their } \\
\text { work/education }\end{array}$ & 85 & $29 \%$ \\
\hline Lack of interest in sports & 76 & $27 \%$ \\
\hline Sleeplessness & 70 & $24 \%$ \\
\hline Anxiety & 65 & $20 \%$ \\
\hline Total & $\mathbf{2 9 6}$ & $\mathbf{1 0 0}$ \\
\hline
\end{tabular}

Most of the users $29 \%$ of the respondents faced lack of interest towards their work/ education, $27 \%$ felt lack of interest in sports, $24 \%$ suffered from sleeplessness and $20 \%$ had Anxiety problems.

\section{Conclusions}

The research under-review aimed to evaluate the increasing trend of Sheesha smoking among the youth and examine their awareness regarding its health consequences. The results yielded eye-opening facts:

$>$ Sheesha is very common in Muslims rather than Christianity or Hinduism as it is inherited from Mughal culture.

$>$ In Karachi city it is frequently used among Urdu speaking families as compare to other ethnic communities.

$>$ It shows that youth belongs to different educational status is involved in this habit. Moreover the large majority of them belong to private educational institutions.

$>$ Sheesha cafes are famous among the youth because mostly cafes have open air environment which attract them more. 
It is very alarming that the youth started smoking sheesha in early teenage introduced by their friends. Surprisingly their families know about their habit but they don't stop them and unfortunately they react normally towards it.

$>$ This habit prevails among female youth also, without considering its health consequences.

This vulnerable reality calls for immediate action not only on the part of the government, policy makers, NGO law enforcement agencies, city government but also health care providers, teachers, social workers and social response in creating awareness against the hazards linked with sheesha smoking.

\section{Recommendations}

In the light of the findings the following recommendations have been drawn:

$>$ Parents should be very vigilant regarding the outdoor activities of their children.

$>$ Families should aware their children about the consequences of sheesha on their life in general.

$>$ The public should educate about the effects of sheesha smoking on war footing, government machinery, NGOs and mass media should collaborate for this cause.

$>$ Professional social workers should involve in the awareness raising campaign as they effectively work as social mobilizes, communicators and counsellors.

$>$ Teachers can play vital role in anti-sheesha smoking campaigns. Special seminars should be arranged in schools, colleges and universities to warn the students against the sheesha habit.

$>$ Sheesha cafes must be banned and law should be enforced in Pakistan.

$>$ Government must restrict by law the restaurants owners to serve sheesha in their premises. Health institution should play their role in sharing information about the effects of sheesha smoking on human body.

$>$ A public awareness message should be disseminate through all print and electronic media.

The following recommendations are proposed and effort at all level required implementing them. Some of these are also suggested actions by the WHO study group on tobacco product regulations (WHO: advisory note: 2006)

1. Sheesha should be subjected to the same regulations as cigarettes and other tobacco products.

2. Sheesha should contain health warnings.

3. The restaurants should inform their clients of their actual contents of sheesha.

4. Media should be involved in creating awareness against the hazards of sheesha smoking 
5. Awareness sessions against the hazards of sheesha smoking and other substances abuses should be made a regular feature in all educational institutions.

6. Surveys should be conducted to assess the extent of the problem and its prevalence in our society.

\section{References}

Ahmad K, Jafary F, Jehan I, Hatcher J. Khan AQ, Chaturvedi N, et al Prevalence and Predictors of Smoking in Pakistan: Results of the National Healthy Survey of Pakistan. Eur J. Cardiovascular Prev Rehabil 2005; 12:203-8

Eissenburg T, warid KD, Smith-Simone S, Mazaik W (2008). Water pipe tobacco smoking on a U.S.college campus: prevalence and correlates' Adolesc health, 42,526-9.

Ganatra HA, Kalia S, Haque AS, Kahan JA, Cigarette Smoking Among Adolescent Females in Pakistan. Int J Tuberc Lung Dis 2007; 11: 1366-71.

Global youth Tobacco survey collaborating Group. Differences in worldwide tobacco use by gender: findings from the global youth tobacco survey.J Sch S health 2003; 73:207-15.

Jawaid A, Zafar AM, Rehaman TU, Nazir MR, Ghafoor ZA Afzal O, (2008) Knowledge, Attitudes and Practice of University Students Regarding Water Pipe Smoking in Pakistan. Int J Tuberc Lung Dis; 12:1077-84.

Khan, J. (2012) Tobacco Epidemic in Pakistan, J Postgrad Medical Institution; 26(3):2336 jpmi.org.pk/index.php/jpmi/article/download/1293/1242

Mazaik W, Eissenberg T, Ratam S, et al (2004). Beliefs and attitudes related to narghile(water pipe) smoking among university students in Syria. Ann epidemiol, $14,646-54$.

Mazaik W, Ward KD, Afifi Sowied RA, Eissenberg T(2004), Tobacco smoking using a water pipe: A re-emerging strain in a global epidemic. Tob control 2004; 13:32733

Mazaik W, Ward KD, Afifi Sowied RA, Eissenberg T, Tobacco smoking using a water pipe: A re-emerging strain in a global epidemic. Tob control 2004; 13:327-33. 
Mazaik W, Ward KD, Mzayek F, et al (2005), mapping the health and environmental situation in informal zones in Aleppo, Syria: report from the Aleppo household survey. Int Arch.

Mushtaq N, Mushtaq s, Beebe LA. Economics of tobacco control in Pakistan: estimating lasticities of cigrattes demand. Tob control 2011; 20:431-5.

Nawaz H, Imam SZ, Zubairi AB, Pabaney AH, Sepah YJ, Islam M, et al. (2007) Smoking habits and beliefs of future physicians of Pakistan. Int $\mathbf{J}$ Tuberc Lung Dis; Aug; 11(8):915-9.

US Department of Health and Human Services , "The Health Consequences of Smoking: A Report of the Surgeon General-Executive Summary" . Atlanta GA: US Department of Health and Human Services, Centers for Disease Control and Prevention, National Center for Chronic Disease Control and Health Promotion, Office on Smoking and Health. (2004), WHO, 2005. http://www.who.int/tobacco/global_interaction/tobreg/en/ accessed March 2013

WHO (2008) World Health Organization on the Global Tobacco Epidemic. :http://www.who.int/tobacco/mpower_report_full_2008.Pdf.accessed on 26-march-2013)

WHO, advisory note: water pipe tobacco smoking health effects, research needs and recommendation actions by regulator / WHO study group on tobacco product regulations 2006 http:/www.who.int/tobacco/global interaction/tobreg/ water pipe/en/index.html. (Accessed on 14-march2013)

WHO,2005.http://www.who.int/tobacco/global_interaction/tobreg/en/accessed March 2013.

Wikipedia, https://en.wikipedia.org/wiki/Hookah

World health organization (2005) Tobacco regulatory advisory note water pipe tobacco smoking: health effects, research needs and recommended actions by regulators. Geneva

World health organization, tobacco free initiative, (2003-2004) http:/www.who.int/ tobacco/resources/publications/tfi_final_26Jan.pdf 
World Health Organizations (2010) (Tobacco Free Initiative). Advisory note water pipe tobacco smoking: health effects, research needs and recommended actions by regulators. Geneva .Switzerland:[WHO]Why is tobacco a public health priority?.

Dr. Syeda Farhana Sarfaraz is Assistant Professor in the Department of Social Work, University of Karachi.

Ms. Sakina Riaz is Assistant Professor in the Department of Social Work, University of Karachi.

Dr. Sumera Ishrat is Assistant Professor in the Department of Social Work, University of Karachi. 